\title{
Synthesis and Fluorescence Properties of Asymmetrical Salamo-Type Tetranuclear Zinc(II) Complex
}

\author{
Yun-Dong Peng, Xiao-Yan Li, Quan-Peng Kang, Gao-Xian An, Yang Zhang and Wen-Kui Dong * \\ School of Chemical and Biological Engineering, Lanzhou Jiaotong University, Lanzhou 730070, China; \\ pengyundong6@126.com (Y.-D.P.); L1401569787@163.com (X.-Y.L.); KQpeng2580@163.com (Q.-P.K.); \\ angaoxian123@163.com (G.-X.A.); zhangy8124@163.com (Y.Z.) \\ * Correspondence: dongwk@126.com; Tel.: +86-931-4938-703
}

Received: 25 January 2018; Accepted: 22 February 2018; Published: 24 February 2018

\begin{abstract}
A new tetranuclear zinc(II) complex with an asymmetrical Salamo-type chelating ligand, $\mathrm{H}_{3} \mathrm{~L}$ (5-methoxy-6'-hydroxy-2,2'-[ethylenedioxybis(nitrilomethylidyne)]diphenol), was synthesized and characterized using FT-IR, elemental analyses, X-ray single crystal diffraction method, UV-Vis, and fluorescence spectra. The zinc(II) complex possesses the cell parameters $a=8.1960$ (7) $\AA, b=9.8127(8) \AA$, $c=16.5428(15) \AA, Z=1, V=1172.5(2) \AA^{3}, R_{1}=0.0722$, and $w R_{2}=0.1558$, and crystallizes in the triclinic system, with space group $P$-1. X-ray crystal structure analysis reveals that Zn1 and Zn2 atoms are all pentacoordinated and adopt slightly twisted tetragonal pyramidal and trigonal bipyramidal geometries. The zinc(II) complex forms a 1D supramolecular chain via intermolecular hydrogen bonds along the $b$ axis. Besides, the fluorescence properties have been discussed.
\end{abstract}

Keywords: Salamo-type ligand; zinc(II) complex; synthesis; crystal structure; fluorescence property

\section{Introduction}

Over the past years, research has shown the Salen-type [1-8] and Salamo-type [9-17] compounds to be exceptionally good chelating ligands in in the fields of organometallic chemistry and coordination chemistry. The Salamo metal complexes are widely utilized in various fields such as industrial catalyses [18,19], biological fields [20,21], ion recognitions [22-24], environmental sciences [25-28], and magnetic $[29,30]$ and luminescent materials [31-39]. Recently, a lot of researchers have tried many approaches to change the $\left(-\mathrm{CH}=\mathrm{N}-\left(\mathrm{CH}_{2}\right)_{n}-\mathrm{N}=\mathrm{CH}-\right)$ instead of $\left(-\mathrm{CH}=\mathrm{N}-\mathrm{O}-\left(\mathrm{CH}_{2}\right)_{n}-\mathrm{O}-\mathrm{N}=\mathrm{CH}-\right)$ unit in order to make the exchange reaction and hydrolysis reaction rate of the compounds greatly reduced and the balance level raised to a very great extent, so the Salamo-type compounds are more stable than the Salen-type compounds [40-42]. Research on Salen-type compounds has yet to be fully explored. Besides, their complexes often form supramolecular systems that have unique structures, a novel bonding pattern, a specific microstructure, and excellent macroscopic properties by the intermolecular association of the weak non-covalent bonding [43-45]. More ideal structural variations, drastic changes in characteristics of the previous complexes, and novel properties could be obtained through the asymmetric configuration. Herein, a new asymmetrical Salamo-type compound, 5-methoxy-6'-hydroxy-2,2'-(ethylenedioxybis(nitrilomethylidyne))diphenol $\left(\mathrm{H}_{3} \mathrm{~L}\right)$ and its zinc(II) complex, were designed and synthesized and structurally characterized. 


\section{Experimental}

\subsection{Materials and Measurements}

3-hydroxysalicyladehyde (99\%) and 4-Methoxysalicylaldehyde (98\%) were purchased from Alfa Aesar (New York, NY, USA), while Tianjin Chemical Reagent Factory supplied the remaining reagents. Elemental analysis for zinc was detected by IRIS ER/S-WP-1 ICP atomic emission spectrometer (Elementar, Berlin, Germany). C, H, and N were analyzed using GmbH VariuoEL V3.00 automatic elemental analysis instrument (Elementar, Berlin, Germany). IR spectra $\left(400-4000 \mathrm{~cm}^{-1}\right)$ were recorded on a Vertex 70 FT-IR spectrophotometer (Bruker, Billerica, MA, USA), with samples prepared as $\mathrm{KBr}$ pellets. UV-vis absorption spectra were recorded on a Shimadzu UV-3900 spectrometer (Shimadzu, Tokyo, Japan). ${ }^{1} \mathrm{H}$ NMR spectra were determined by German Bruker AVANCE DRX-400/600 spectroscopy (Bruker AVANCE, Billerica, MA, USA). Fluorescence spectra were recorded on an F-7000 FL spectrophotometer (Hitachi, Tokyo, Japan). X-ray single crystal structure determination of the zinc(II) complex was carried out on a SuperNova Dual (Cu at zero) four-circle diffractometer.

\subsection{Synthesis of $\mathrm{H}_{3} \mathrm{~L}$}

The synthesis of 5-methoxy-6'-hydroxy-2, 2'-[ethanedioxybis(nitrilomethylidyne)]diphenol $\left(\mathrm{H}_{3} \mathrm{~L}\right.$ ) is given (Scheme 1).

1,2-Bis(aminooxy)ethane and 2-[O-(1-ethyloxyamide)]oxime-5-methoxyphenol were synthesized according to an analogous method reported earlier $[15,46]$. A colorless ethanol solution $(4 \mathrm{~mL})$ of 2,3-dihydroxybenzaldehyde $(256.32 \mathrm{mg}, 2.0 \mathrm{mmol}$ ) was slowly added to the ethanol solution (4 $\mathrm{mL}$ ) of 2-[O-(1-ethyloxyamide)]oxime-5-methoxyphenol $(425.05 \mathrm{mg}, 2.0 \mathrm{mmol})$, and the mixture was stirred at $52{ }^{\circ} \mathrm{C}$ for $6 \mathrm{~h}$. After cooling to room temperature, the precipitate was filtered and washed successively with ethanol and ethanol-hexane $(1: 4)(3 \times 4 \mathrm{~mL})$, respectively. The product was purified with recrystallization from ethanol and dried in vacuo to get a yellow powder. Yield: $80.7 \%$. m.p. 110-111.5 ${ }^{\circ} \mathrm{C}$. Anal. calcd. for $\mathrm{C}_{17} \mathrm{H}_{18} \mathrm{~N}_{2} \mathrm{O}_{6}(\%)$ : C 59.84, H 6.21, N 7.41; found: C 59.66, H 6.12, N 7.73. ${ }^{1} \mathrm{H}$ NMR $\left(400 \mathrm{MHz}, \mathrm{CDCl}_{3}\right) \delta 9.92(\mathrm{~d}, J=7.8 \mathrm{~Hz}, 2 \mathrm{H}), 8.19(\mathrm{~d}, J=18.3 \mathrm{~Hz}, 1 \mathrm{H}), 7.05(\mathrm{~d}, J=8.4 \mathrm{~Hz}, 1 \mathrm{H})$, $6.96(\mathrm{~d}, J=7.2 \mathrm{~Hz}, 1 \mathrm{H}), 6.87-6.71(\mathrm{~m}, 2 \mathrm{H}), 6.53-6.44(\mathrm{~m}, 2 \mathrm{H}), 4.47(\mathrm{~d}, J=6.7 \mathrm{~Hz}, 3 \mathrm{H}), 3.81(\mathrm{~s}, 4 \mathrm{H})$.

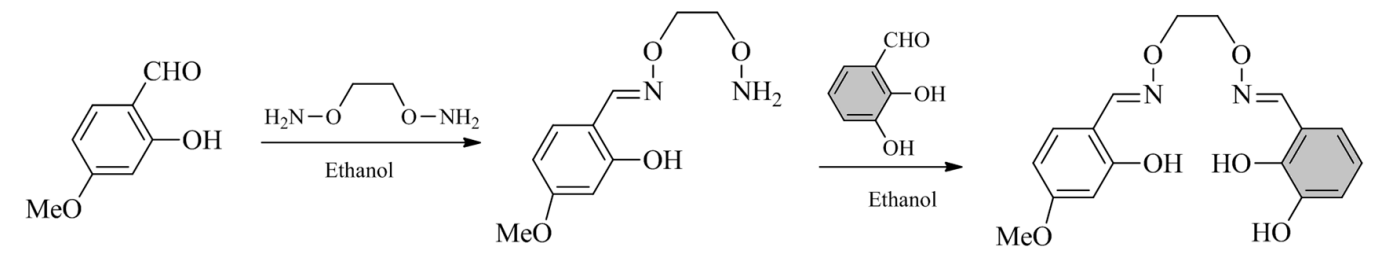

Scheme 1. Routes to the synthesis of ligand $\mathrm{H}_{3} \mathrm{~L}$.

\subsection{Synthesis of the Zinc(II) Complex}

A dropwise solution of $\mathrm{Zn}\left(\mathrm{CH}_{3} \mathrm{COO}\right)_{2} \cdot \mathrm{H}_{2} \mathrm{O}(8.78 \mathrm{mg}$, $4 \mathrm{mmol})$ in ethanol $(9 \mathrm{~mL})$ was added to a solution of $\mathrm{H}_{3} \mathrm{~L}(6.84 \mathrm{mg}, 2 \mathrm{mmol})$ in chloroform $(5 \mathrm{~mL})$ at r.t., after which the mixed solution was stirred for $6 \mathrm{~h}$ at $60{ }^{\circ} \mathrm{C}$ and was then filtered off. The filtrate was allowed to stand at r.t. for several days, and yellow prismatical single crystals suitable for $\mathrm{X}$-ray crystallographic analysis were obtained. Yield: 51.6\%. Anal. calcd. for $\mathrm{C}_{42} \mathrm{H}_{48} \mathrm{~N}_{4} \mathrm{Zn}_{4} \mathrm{O}_{18}$ (\%): C, 43.54; $\mathrm{H}, 4.19 ; \mathrm{N}, 4.89 ; \mathrm{Zn}, 22.55$. Found: $\mathrm{C}, 43.55 ; \mathrm{H}, 4.18 ; \mathrm{N}, 4.84 ; \mathrm{Zn}, 22.58$. Table 1 shows the data collection and refinements of the zinc(II) complex.

\subsection{X-ray Crystallography}

Single crystal X-ray diffraction data were collected at $173 \mathrm{~K}$ on a SuperNova Dual $(\mathrm{Cu}$ at zero) four-circle diffractometer with graphite-monochromated Mo- $K \alpha$ radiation $(\lambda=0.71073 \AA)$. The 
structure was solved by the direct methods and all hydrogen atoms were added. All non-hydrogen atoms were refined anisotropically using a full-matrix least-squares procedure on $F^{2}$ with SHELXL-2014 [47,48]. The LP factor and semi-empirical absorption correction by SADABS were applied to the intensity data. The crystal data and experimental parameters relevant to the structure determination are listed in Table 1, and the final positional and thermal parameters are available as supplementary material.

Table 1. Crystal data and structure refinement for the zinc(II) complex.

\begin{tabular}{|c|c|}
\hline Molecular Formula & $\mathrm{C}_{42} \mathrm{H}_{48} \mathrm{~N}_{4} \mathrm{Zn}_{4} \mathrm{O}_{18}$ \\
\hline Formula weight & 1158.32 \\
\hline Temperature (K) & 221 \\
\hline Wavelength $(\AA)$ & 0.71073 \\
\hline Crystal system & triclinic \\
\hline Space group & $P-1$ \\
\hline$a(\AA)$ & $8.1960(7)$ \\
\hline$b(\AA)$ & $9.8127(8)$ \\
\hline$c(\AA)$ & $16.5428(15)$ \\
\hline$\alpha\left({ }^{\circ}\right)$ & $106.392(8)$ \\
\hline$\beta\left(^{\circ}\right)$ & $92.669(8)$ \\
\hline$\gamma\left({ }^{\circ}\right)$ & $111.299(8)$ \\
\hline$V\left(\AA^{3}\right)$ & $1172.5(2)$ \\
\hline Z & 1 \\
\hline$D_{\text {calc }}\left(\mathrm{g} \cdot \mathrm{cm}^{-3}\right)$ & 1.640 \\
\hline$\mu\left(\mathrm{mm}^{-1}\right)$ & 2.099 \\
\hline$F(000)$ & 592 \\
\hline Crystal size (mm) & $0.21 \times 0.23 \times 0.25$ \\
\hline Index range & $\begin{array}{l}-10 \leq h \leq 8 \\
-12 \leq k \leq 12 \\
-18 \leq l \leq 20\end{array}$ \\
\hline Reflections collected & 7315 \\
\hline Independent reflections & 4569 \\
\hline Rint & 0.0620 \\
\hline Completeness to $\theta$ & 3.43 to 26.02 \\
\hline Data/ restraints/parameters & $4569 / 3 / 313$ \\
\hline GOF & 1.027 \\
\hline Final $\mathrm{R}_{1}, \mathrm{wR}_{2}$ indices & $R_{1}=0.0722, w R_{2}=0.1127$ \\
\hline $\mathrm{R}_{1}{ }^{a}, \mathrm{wR}_{2}{ }^{b}$ indices (all data) & $R_{1}=0.1493, w R_{2}=0.1555$ \\
\hline Largest differences peak and hole $\left(\mathrm{e} \AA^{-3}\right)$ & 0.918 and -0.493 \\
\hline
\end{tabular}

Crystallographic data have been deposited with the Cambridge Crystallographic Data Centre as supplementary publication, with CCDC-1519979 for the zinc(II) complex. Copies of the data can be obtained free of charge on application to CCDC, 12 Union Road, Cambridge CB21EZ, UK (Telephone: +(44)-01223-762910; Fax: +44-1223-336033; E-mail: deposit@ccdc.cam.ac.uk). These data can be also obtained free of charge at www.ccdc.cam.ac.uk/conts/retrieving.html.

\section{Results and Discussion}

\subsection{FT-IR Spectra}

The most important features in the FT-IR spectra data of $\mathrm{H}_{3} \mathrm{~L}$ and its zinc(II) complex are listed in Table 2. 
Table 2. Infrared absorption spectra of $\mathrm{H}_{3} \mathrm{~L}$ and its zinc(II) complex $\left(\mathrm{cm}^{-1}\right)$.

\begin{tabular}{cccccc}
\hline Compound & $v(\mathbf{O}-\mathbf{H})$ & $v(\mathrm{C}=\mathbf{N})$ & $v(\mathbf{A r}-\mathrm{O})$ & $v(\mathbf{Z n}-\mathbf{N})$ & $v(\mathrm{Zn}-\mathrm{O})$ \\
\hline $\mathrm{H}_{3} \mathrm{~L}$ & 3439 & 1631 & 1283 & - & - \\
{$\left[\left\{\mathrm{Zn}(\mathrm{L})(\mu-\mathrm{OAc}) \mathrm{Zn}\left(\mathrm{CH}_{3} \mathrm{CH}_{2} \mathrm{OH}\right)\right\}_{2}\right]$} & 3424 & 1600 & 1265 & 509 & 467 \\
\hline
\end{tabular}

Data obtained from the FT-IR spectra show differences between $\mathrm{H}_{3} \mathrm{~L}$ and its zinc(II) complex, and the analysis gives hint about the coordination reaction between $\mathrm{H}_{3} \mathrm{~L}$ and zinc(II) atoms, and thus suggests formation of a new zinc(II) complex. The characteristic $\mathrm{C}=\mathrm{N}$ stretching band of $\mathrm{H}_{3} \mathrm{~L}$ is found at $1631 \mathrm{~cm}^{-1}$, and that of zinc(II) complex appears at $1600 \mathrm{~cm}^{-1}$ [49-51]. Upon complexation, this band shifts by a ca. $31 \mathrm{~cm}^{-1}$ to a lower frequency, and thus indicates that $\mathrm{C}=\mathrm{N}$ bond order decreases owing to the binding of the zinc(II) atom to oxime nitrogen atoms [40]. The stretching frequency band of the Aromatic-O atom appears at $1283 \mathrm{~cm}^{-1}$ for $\mathrm{H}_{3} \mathrm{~L}$, while for the zinc(II) complex the band appears at $1265 \mathrm{~cm}^{-1}$ [40,52]. The frequency shift in the Aromatic-O stretching band shows that interaction between the oxygen atoms of phenolic group and zinc(II) atom results in the $\mathrm{Zn}-\mathrm{O}$ bonds formation [46]. Besides, the $\mathrm{O}-\mathrm{H}$ stretching band of $\mathrm{H}_{3} \mathrm{~L}$ is observed at $3439 \mathrm{~cm}^{-1}$, while the absorption broad band at $3424 \mathrm{~cm}^{-1}$ in the zinc(II) complex could be ascribed to the -OH group of coordinated ethanol molecules.

\subsection{UV-Vis Absorption Spectra}

The data and absorption spectra of $\mathrm{H}_{3} \mathrm{~L}$ and its zinc(II) complex in diluted ethanol solution were presented in Figure 1. The spectrum of the zinc(II) complex is different from that of the free ligand $\mathrm{H}_{3} \mathrm{~L}$. The UV-Vis spectrum of the free ligand $\mathrm{H}_{3} \mathrm{~L}$ exhibits one absorption peak at ca. $275 \mathrm{~nm}$ and could be attributed to the $\pi-\pi^{*}$ transition of the benzene rings.

The zinc(II) complex exhibits maximum absorption peak at $289 \mathrm{~nm}$, which indicates that coordination reaction occurs between the zinc(II) atoms and $\mathrm{H}_{3} \mathrm{~L}$ [46]. Moreover, a new absoption peak at $340 \mathrm{~nm}$ was observed in the zinc(II) complex, contrary to the peak observed at $311 \mathrm{~nm}$ in $\mathrm{H}_{3} \mathrm{~L}$, which could be attributed to the $\pi-\pi^{*}$ transition of the oxime group [46].

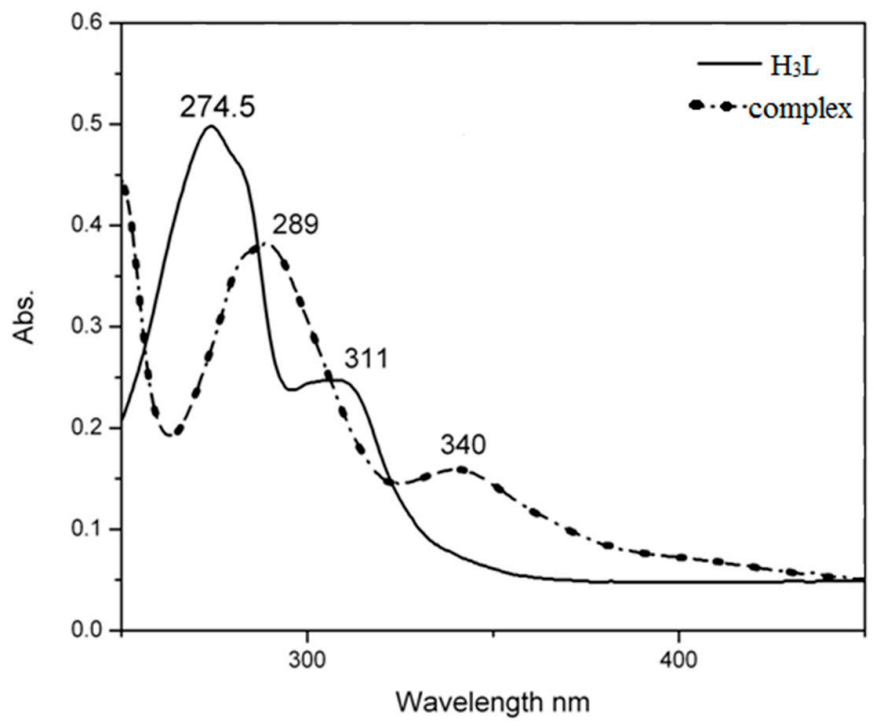

Figure 1. UV-Vis absorption spectra of $\mathrm{H}_{3} \mathrm{~L}$ and its zinc(II) complex in ethanol $\left(3.0 \times 10^{-5} \mathrm{~mol} / \mathrm{L}\right)$.

\subsection{Crystal and Supramolecular Structure of the Zinc(II) Complex}

The zinc(II) complex crystal structure is depicted in Figure 2, while Table 3 shows the list of important bond distances and bond angles. 


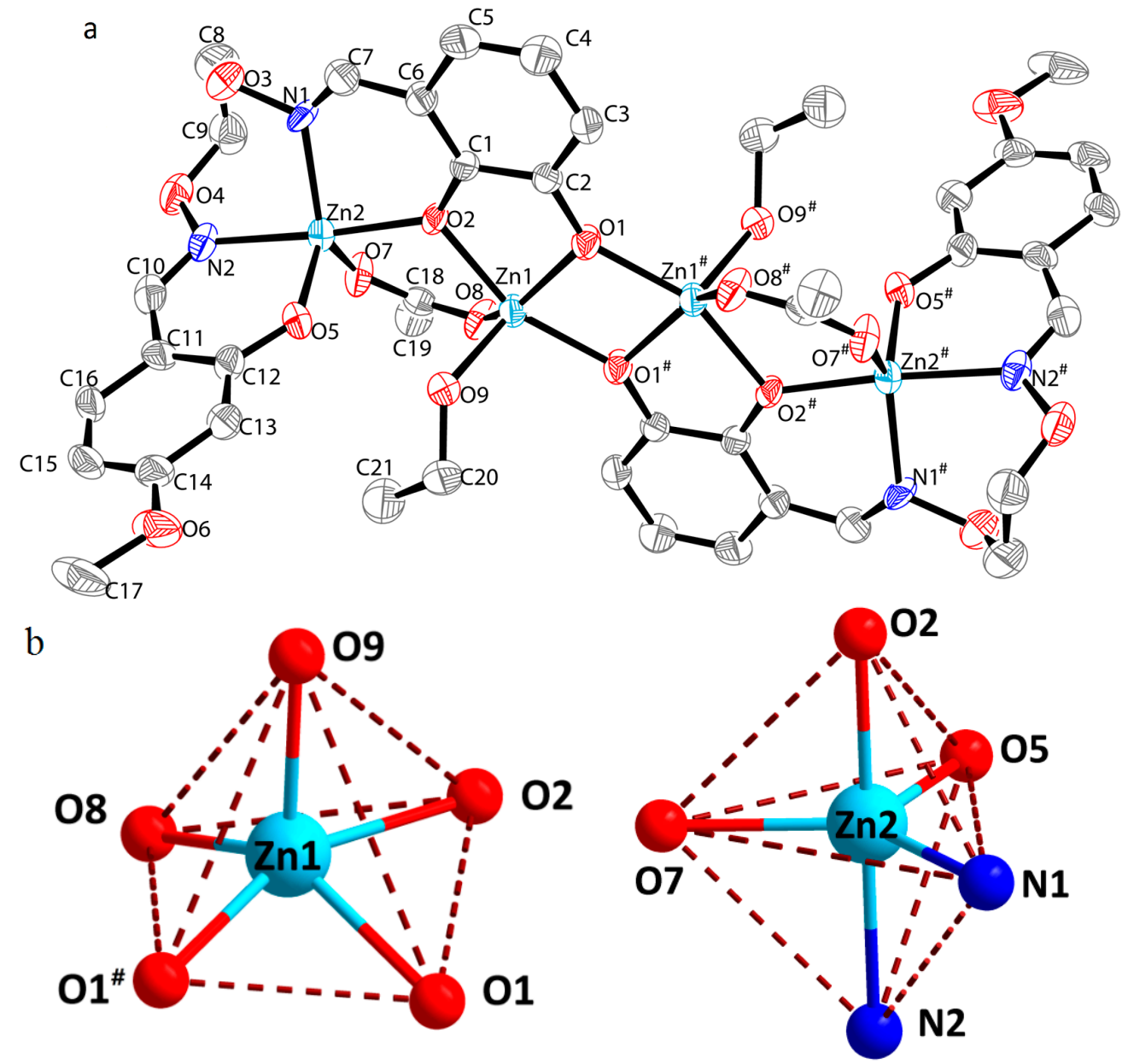

Figure 2. (a) View of the molecular structure of the zinc(II) complex with atom labeling (hydrogen atoms are omitted for clarity purpose and are drawn at the $30 \%$ probability level). (b) View of zinc(II) atoms of the zinc(II) complex showing coordination polyhedrons.

Table 3. Selected bond distances $(\AA)$ and bond angles $\left(^{\circ}\right)$ of the zinc(II) complex.

\begin{tabular}{cccccc}
\hline Bond & Lengths & Bond & Lengths & Bond & Lengths \\
\hline Zn1-O1 & $2.039(5)$ & Zn1-O2 & $2.058(5)$ & Zn1-O8 & $1.963(6)$ \\
Zn1-O9 & $2.026(5)$ & Zn1-O1 & $2.002(5)$ & Zn2-O2 & $2.010(5)$ \\
Zn2-N1 & $2.083(7)$ & Zn2-O5 & $1.940(5)$ & Zn2-O7 & $1.981(6)$ \\
Zn2-N2 & $2.127(7)$ & & & & \\
\hline Bond & Angles & Bond & Angles & Bond & Angles \\
\hline O1-Zn1-O2 & $79.6(2)$ & O1-Zn1-O8 & $140.6(2)$ & O1-Zn1-O9 & $111.2(2)$ \\
O1-Zn1-O1 & $77.7(2)$ & O2-Zn1-O8 & $96.3(2)$ & O2-Zn1-O9 & $89.6(2)$ \\
O2-Zn1-O1 \# & $156.63(2)$ & O8-Zn1-O9 & $107.8(2)$ & O8-Zn1-O1 & $97.9(2)$ \\
O9-Zn1-O1 \# & $103.6(2)$ & O2-Zn2-O5 & $94.0(2)$ & O2-Zn2-O7 & $91.8(2)$ \\
O2-Zn2-N1 & $85.0(3)$ & O2-Zn2-N2 & $175.8(2)$ & O5-Zn2-O7 & $113.1(2)$ \\
O5-Zn2-N1 & $117.4(3)$ & O5-Zn2-N2 & $89.7(3)$ & O7-Zn2-N1 & $129.5(3)$ \\
O7-Zn2-N2 & $88.7(2)$ & N1-Zn2-N2 & $91.5(3)$ & & \\
\hline
\end{tabular}

Symmetry transformations used to generate equivalent atoms: ${ }^{\#}: 2-x, 1-y,-z$.

The complex $\left[\left\{\mathrm{Zn}(\mathrm{L})(\mu \text {-OAc }) \mathrm{Zn}\left(\mathrm{CH}_{3} \mathrm{CH}_{2} \mathrm{OH}\right)\right\}_{2}\right]$ belongs to the triclinic system, with space group $P-1$, and consists of four zinc(II) atoms and two completely deprotonated (L) ${ }^{3-}$ linkers, with two ethanol molecules and two bonded acetate ions. As far as we know, this new 2:4 ((L) ${ }^{3-}$ : zinc(II)) 
Salamo-type zinc(II) coordination complex ratio is rarely reported when compared to its counterpart complexes that have the coordination ratio of 1:1 [46], 2:3 [43], and 4:8 [45] (L: zinc(II)). The terminal zinc(II) atom ( $\mathrm{Zn} 2$ or $\mathrm{Zn2} 2^{\#}$ ) is penta-coordinated, and situated at an $\mathrm{N}_{2} \mathrm{O}_{2}$ site of the deprotonated ligand moiety with one $\mathrm{O} 7$ atom from $\mu$-acetate ion adopting a slightly twisted trigonal bipyramidal geometry $\left(\tau_{2}=0.772\right)$ [11]. The central zinc(II) atom $\left(\mathrm{Zn} 1\right.$ or $\left.\mathrm{Zn} 1^{\#}\right)$ is also penta-coordinated via the three oxygen atoms $\left(\mathrm{O} 1, \mathrm{O} 2\right.$ and $\left.\mathrm{O}^{\#}\right)$, one $\mathrm{O} 9$ atom from the coordinated $\mathrm{EtOH}$ molecule, and one O8 atom from $\mu$-acetate ion forming a slightly distorted tetragonal pyramidal geometry $\left(\tau_{1}=0.265\right)$ [11]. The $\mathrm{Zn} 1$ and $\mathrm{Zn} 2$ atoms are connected through $\mu$-acetate ion in a familiar M-O-C-O-M fashion.

Table 4 summarizes the inter- and intramolecular hydrogen bonds in the zinc(II) complex. From Figure 3, the proton (-C9H9B or $\left.-\mathrm{C}^{\#} \mathrm{H}^{-\mathrm{B}}{ }^{\#}\right)$ of ethylenedioxime carbon atom $\left(\mathrm{C} 9\right.$ or $\left.\mathrm{C} 9^{\#}\right)$ of $(\mathrm{L})^{3-}$ unit is hydrogen bonded to oxygen atom $(\mathrm{O} 7)$ of the $\mu$-acetate ions, and the proton $\left(-\mathrm{O} 9 \mathrm{H} 9\right.$ or $\left.-\mathrm{O} 9^{\#} \mathrm{H} 9^{\#}\right)$ of the coordinated ethanol molecule is hydrogen bonded to one of phenolic oxygen atom ( $\mathrm{O} 5$ or $\left.\mathrm{O}^{\#}\right)$ of the $(\mathrm{L})^{3-}$ unit. Thus, two pairs of intramolecular hydrogen bonds $\mathrm{C} 9-\mathrm{H} 9 \mathrm{~B} \cdots \mathrm{O} 7, \mathrm{C}^{\#}-\mathrm{H}^{\mathrm{B}} \mathrm{B}^{\#} \ldots \mathrm{O}^{\#}$, $\mathrm{O} 9-\mathrm{H} 9 \cdots \mathrm{O} 5$ and $\mathrm{O}^{\#}-\mathrm{H}^{\#} \ldots \mathrm{O}^{\#}{ }^{[53-59]}$ are formed. Under the intermolecular force of $\mathrm{C} 7-\mathrm{H} 7 \ldots \mathrm{O} 6$ and $\mathrm{C}^{\#}-\mathrm{H} 7^{\#} \ldots \mathrm{O}^{\#}$, a $1 \mathrm{D}$ supramolecular chain that extends infinitely in the $b$ axis direction is formed by the crystal of $\left[\left\{\mathrm{Zn}(\mathrm{L})(\mu-\mathrm{OAc}) \mathrm{Zn}\left(\mathrm{CH}_{3} \mathrm{CH}_{2} \mathrm{OH}\right)\right\}_{2}\right]$, as depicted in Figure 4 [60-67].

Table 4. The intra- and intermolecular hydrogen bonds of the $\mathrm{Zn}(\mathrm{II})$ complex.

\begin{tabular}{|c|c|c|c|c|c|}
\hline D-H $\cdots A$ & $\mathrm{~d}(\mathrm{D}-\mathrm{H})(\AA)$ & $\mathrm{d}(\mathrm{H} \cdots \mathrm{A})(\AA)$ & $d(D \cdots A)(\AA)$ & $\angle \mathrm{D}-\mathrm{H} \cdots \mathrm{A}\left({ }^{\circ}\right)$ & Symmetry Code \\
\hline O9-H9...O5 & 0.86 & 1.88 & $2.648(2)$ & 147 & \\
\hline C9-H9B ‥ & 0.97 & 2.53 & $3.336(5)$ & 141 & \\
\hline 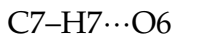 & 0.93 & 2.55 & $3.473(4)$ & 171 & $x, 1+y, z$ \\
\hline
\end{tabular}

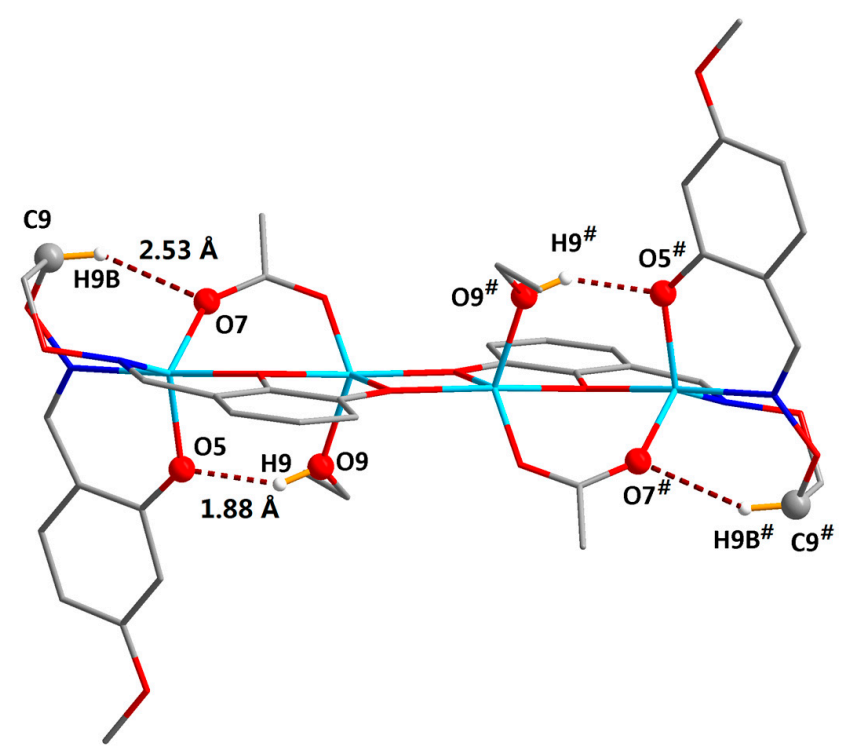

Figure 3. View of the intramolecular hydrogen bonds of the zinc(II) complex unit (for clarity's sake, hydrogen atoms are omitted except those forming hydrogen bonds). 


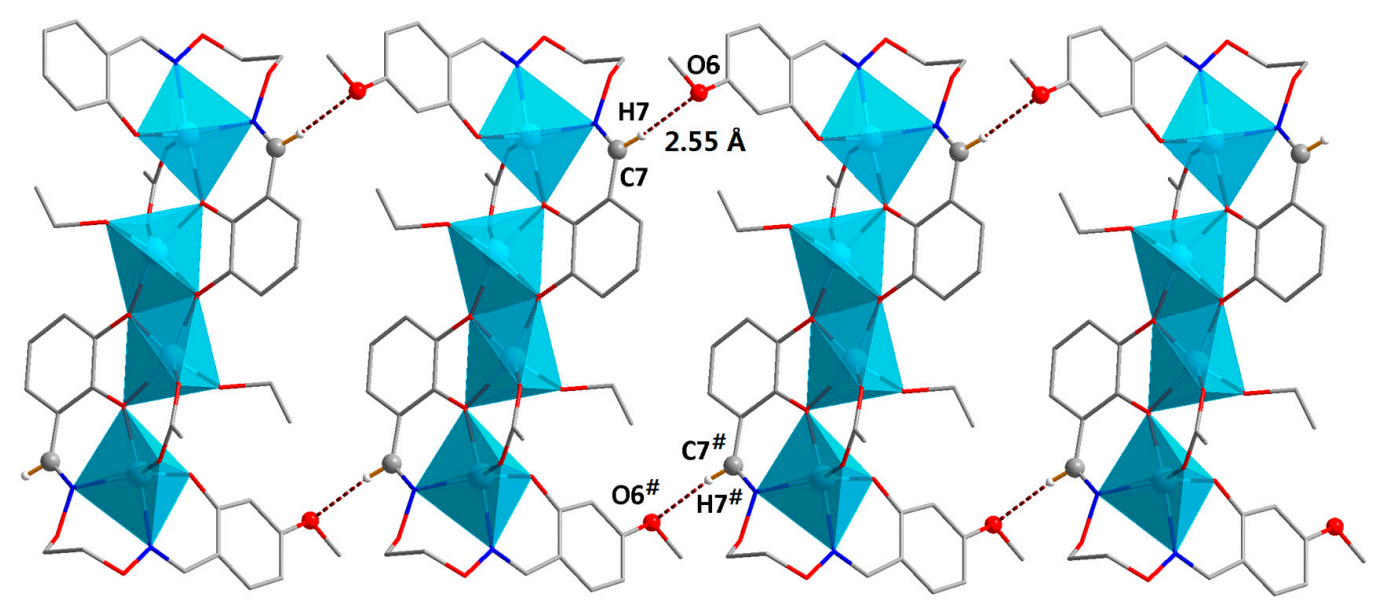

Figure 4. A 1D chain of the zinc(II) complex viewed along the $b$ axis (for clarity's sake, hydrogen atoms are omitted except those forming hydrogen bonds).

\subsection{Fluorescent Properties}

As shown in Figure 5, $\mathrm{H}_{3} \mathrm{~L}$ exhibits a broad emission at $406 \mathrm{~nm}$ upon excitation at $268 \mathrm{~nm}$, while the zinc(II) complex displays an intense photoluminescence with maximum emission peak at ca. $415 \mathrm{~nm}$ upon excitation at $268 \mathrm{~nm}$, which is considered to be bathochromically shifted when compared to that of $\mathrm{H}_{3} \mathrm{~L}$, indicating that molecular inter-atomic forces and degree of conjugation are better in the zinc(II) complex internal molecules, due to the intraligand $\pi-\pi^{*}$ transition [18]. The $\mathrm{Zn}$ (II) complex has a greater fluorescence intensity, and it may have potential as a luminescent material.

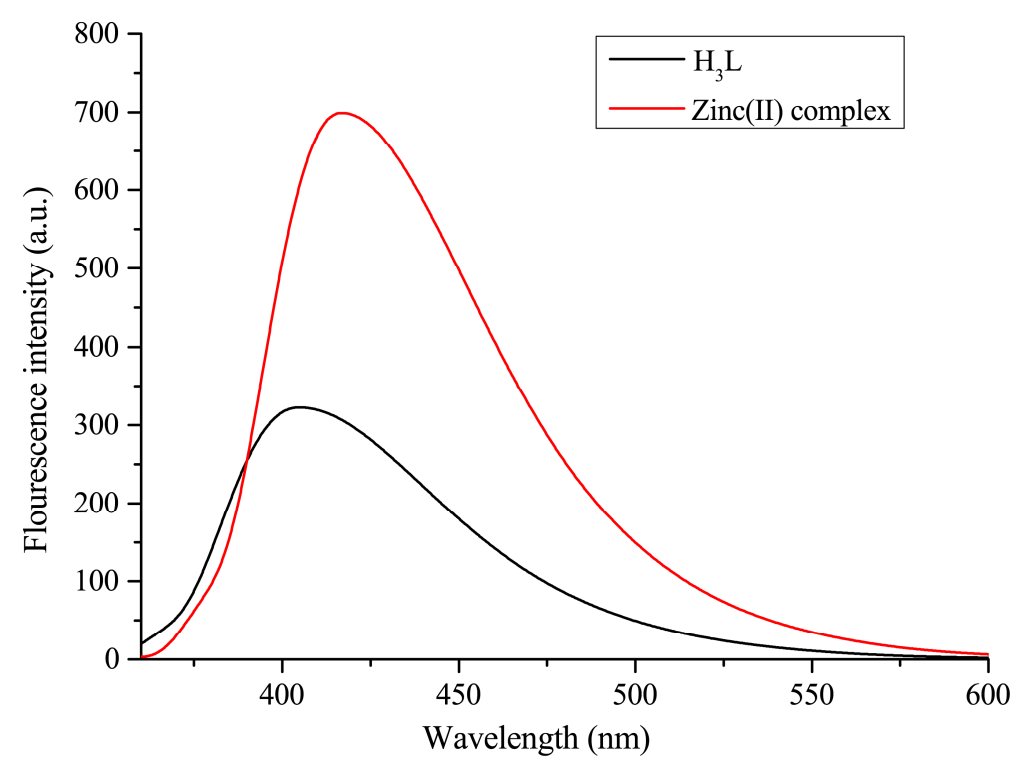

Figure 5. The Fluorescence spectra of $\mathrm{H}_{3} \mathrm{~L}$ and its zinc(II) complex in methanol $\left(3.0 \times 10^{-5} \mathrm{~mol} / \mathrm{L}\right)$.

\section{Concluding Remarks}

In this paper, A new tetranuclear zinc(II) complex has been successfully prepared and characterized. X-ray crystal structure analysis reveals that the four zinc(II) atoms are all penta-coordinated, in which two of the zinc(II) atoms lie in the $\mathrm{N}_{2} \mathrm{O}_{2}$ coordination spheres of Salamo-type bis-oxime $(\mathrm{L})^{3-}$ moieties and adopt slightly distorted trigonal bipyramid geometries $\left(\tau_{2}=0.772\right)$, and the remaining two zinc(II) atoms adopt slightly distorted tetragonal pyramidral geometries $\left(\tau_{1}=0.265\right)$. Moreover, the zinc(II) complex molecules assemble to form an infinite $1 \mathrm{D}$ 
chain-like supramolecular structure via intermolecular $\mathrm{C} 7-\mathrm{H} 7 \cdots \mathrm{O} 6$ and $\mathrm{C} 7^{\#}-\mathrm{H} 7^{\#} \ldots \mathrm{O} 6^{\#}$ hydrogen bonding interactions. The fluorescence properties show that the $\mathrm{Zn}(\mathrm{II})$ complex may has the potential to be used as a luminescent material.

Acknowledgments: This work was supported by the National Natural Science Foundation of China (21761018) and the Program for Excellent Team of Scientific Research in Lanzhou Jiaotong University (201706), which is gratefully acknowledged.

Author Contributions: Wen-Kui Dong conceived and designed the experiments; Quan-Peng Kang performed the experiments; Gao-Xian An analyzed the data; Yang Zhang contributed reagents/materials/analysis tools; Yun-Dong Peng and Xiao-Yan Li wrote the paper.

Conflicts of Interest: The authors declare no competing financial interests.

\section{References}

1. Dong, X.Y.; Akogun, S.F.; Zhou, W.M.; Dong, W.K. Tetranuclear Zn(II) complex based on an asymmetrical Salamo-type chelating ligand: Synthesis, structural characterization, and fluorescence property. J. Chin. Chem. Soc. 2017, 64, 412-419. [CrossRef]

2. Song, X.Q.; Liu, P.P.; Liu, Y.A.; Zhou, J.J.; Wang, X.L. Two dodecanuclear heterometallic $\left[Z_{6} \operatorname{Ln}_{6}\right]$ clusters constructed by a multidentate salicylamide salen-like ligand: Synthesis, structure, luminescence and magnetic properties. Dalton Trans. 2016, 45, 8154-8163. [CrossRef] [PubMed]

3. Liu, P.P.; Sheng, L.; Song, X.Q.; Xu, W.Y.; Liu, Y.A. Synthesis, structure and magnetic properties of a new one dimensional manganese coordination polymer constructed by a new asymmetrical ligand. Inorg. Chim. Acta 2015, 434, 252-257. [CrossRef]

4. Wu, H.L.; Bai, Y.C.; Zhang, Y.H.; Li, Z.; Wu, M.C.; Chen, C.Y.; Zhang, J.W. Synthesis, crystal structure, antioxidation and DNA-binding properties of a dinuclear copper(II) complex with bis( $N$-salicylidene)-3-oxapentane-1,5-diamine. J. Coord. Chem. 2014, 67, 3054-3066. [CrossRef]

5. Chen, C.Y.; Zhang, J.W.; Zhang, Y.H.; Yang, Z.H.; Wu, H.L. Gadolinium(III) and dysprosium(III) complexes with a Schiff base bis( $N$-salicylidene)-3-oxapentane-1,5-diamine: Synthesis, characterization, antioxidation, and DNA-binding studies. J. Coord. Chem. 2015, 68, 1054-1071. [CrossRef]

6. Song, X.Q.; Liu, P.P.; Xiao, Z.R.; Li, X.; Liu, Y.A. Four polynuclear complexes based on a versatile salicylamide salen-like ligand: Synthesis, structural variations and magnetic properties. Inorg. Chim. Acta 2015, 438, 232-244. [CrossRef]

7. Sun, Y.X.; Zhang, S.T.; Ren, Z.L.; Dong, X.Y.; Wang, L. Synthesis, characterization, and crystal structure of a new supramolecular $\mathrm{Cd}^{\mathrm{II}}$ complex with halogen-substituted salen-type bisoxime. Synth. React. Inorg. Met.-Org. Nano-Met. Chem. 2013, 43, 995-1000. [CrossRef]

8. Sun, Y.X.; Zhang, Y.J.; Meng, W.S.; Li, X.R.; Lu, R.E. Synthesis and crystal structure of new nickel(II) complex with Salen-type bisoxime ligand. Asian J. Chem. 2014, 26, 416-418.

9. Sun, Y.X.; Gao, X.H. Synthesis, characterization, and crystal structure of a new $\mathrm{Cu}{ }^{\mathrm{II}}$ complex with salen-type ligand. Synth. React. Inorg. Met.-Org. Nano-Met. Chem. 2011, 41, 973-978. [CrossRef]

10. Zhao, L.; Dang, X.T.; Chen, Q.; Zhao, J.X.; Wang, L. Synthesis, Crystal Structure and Spectral Properties of a 2D Supramolecular Copper(II) Complex with 1-(4-\{[(E)-3-ethoxyl-2-hydroxybenzylidene] amino\}phenyl)ethanone Oxime. Synth. React. Inorg. Met.-Org. Nano-Met. Chem. 2013, 43, 1241-1246. [CrossRef]

11. Dong, W.K.; Ma, J.C.; Zhu, L.C.; Zhang, Y. Self-assembled zinc(II)-lanthanide(III) heteromultinuclear complexes constructed from 3-MeOsalamo ligand: Syntheses, structures and luminescent properties. Cryst. Growth Des. 2016, 16, 6903-6914. [CrossRef]

12. Wang, P.; Zhao, L. Synthesis, structure and spectroscopic properties of the trinuclear cobalt(II) and nickel(II) complexes based on 2-hydroxynaphthaldehyde and bis(aminooxy)alkane. Spectrochim. Acta Part A 2015, 135, 342-350. [CrossRef] [PubMed]

13. Sun, Y.X.; Wang, L.; Dong, X.Y.; Ren, Z.L.; Meng, W.S. Synthesis, characterization, and crystal structure of a supramolecular $\mathrm{Co}^{\mathrm{II}}$ complex containing Salen-type bisoxime. Synth. React. Inorg. Met.-Org. Nano-Met. Chem. 2013, 43, 599-603. [CrossRef]

14. Dong, X.Y.; Sun, Y.X.; Wang, L.; Li, L. Synthesis and structure of a penta- and hexa-coordinated tri-nuclear cobalt(II) complex. Chem. Res. 2012, 36, 387-390. [CrossRef] 
15. Wang, P.; Zhao, L. An infinite 2D supramolecular cobalt(II) complex based on an asymmetric Salamo-type ligand: Synthesis, crystal structure, and spectral properties. Synth. React. Inorg. Met.-Org. Nano-Met. Chem. 2016, 46, 1095-1101. [CrossRef]

16. Sun, Y.X.; Xu, L.; Zhao, T.H.; Liu, S.H.; Liu, G.H.; Dong, X.T. Synthesis and crystal structure of a 3D supramolecular copper(II) complex with 1-(3-\{[(E)-3-bromo-5-chloro-2-hydroxybenzylidene]amino\}phenyl) ethanone oxime. Synth. React. Inorg. Met.-Org. Nano-Met. Chem. 2013, 43, 509-513. [CrossRef]

17. Wang, L.; Ma, J.C.; Dong, W.K.; Zhu, L.C.; Zhang, Y. A novel Self-assembled nickel(II)-cerium(III) heterotetranuclear dimer constructed from $\mathrm{N}_{2} \mathrm{O}_{2}$-type bisoxime and terephthalic acid: Synthesis, structure and photophysical properties. Zeitschrift für Anorganische und Allgemeine Chemie 2016, 642, 834-839. [CrossRef]

18. Li, X.Y.; Chen, L.; Gao, L.; Zhang, Y.; Akogun, S.F.; Dong, W.K. Syntheses, crystal structures and catalytic activities of two solvent-induced homotrinuclear $\mathrm{Co}(\mathrm{II})$ complexes with a naphthalenediol-based bis(Salamo)-type tetraoxime ligand. RSC Adv. 2017, 7, 35905-35916. [CrossRef]

19. Li, L.H.; Dong, W.K.; Zhang, Y.; Akogun, S.F.; Xu, L. Syntheses, structures and catecholase activities of homo-and hetero-trinuclear cobalt(II) complexes constructed from an acyclic naphthalenediol-based bis(salamo)-type ligand. Appl. Organomet. Chem. 2017, 31, e3818. [CrossRef]

20. Wang, L.; Hao, J.; Zhai, L.X.; Zhang, Y.; Dong, W.K. Synthesis, crystal structure, luminescence, electrochemical and antimicrobial properties of bis(salamo)-based Co(II) complex. Crystals 2017, 7, 277. [CrossRef]

21. Li, X.Y.; Kang, Q.P.; Liu, L.Z.; Ma, J.C.; Dong, W.K. Trinuclear Co(II) and Mononuclear Ni(II) Salamo-Type Bisoxime Coordination Compounds. Crystals 2018, 8, 43. [CrossRef]

22. Dong, W.K.; Li, X.L.; Wang, L.; Zhang, Y.; Ding, Y.J. A new application of Salamo-type bisoximes: As a relay-sensor for $\mathrm{Zn}^{2+} / \mathrm{Cu}^{2+}$ and its novel complexes for successive sensing of $\mathrm{H}^{+} / \mathrm{OH}^{-}$. Sens. Actuators B Chem. 2016, 229, 370-378. [CrossRef]

23. Wang, F.; Gao, L.; Zhao, Q.; Zhang, Y.; Dong, W.K.; Ding, Y.J. A highly selective fluorescent chemosensor for $\mathrm{CN}^{-}$based on a novel bis(salamo)-type tetraoxime ligand. Spectrochim. Acta A 2018, 190, 111-115. [CrossRef] [PubMed]

24. Dong, W.K.; Akogun, S.F.; Zhang, Y.; Sun, Y.X.; Dong, X.Y. A reversible "turn-on" fluorescent sensor for selective detection of $\mathrm{Zn}^{2+}$. Sens. Actuators B Chem. 2017, 238, 723-734. [CrossRef]

25. Wu, H.L.; Wang, C.P.; Wang, F.; Peng, H.P.; Zhang, H.; Bai, Y.C. A new manganese(III) complex from bis(5-methylsalicylaldehyde)-3-oxapentane-1,5-diamine: Synthesis, characterization, antioxidant activity and luminescence. J. Chin. Chem. Soc. 2015, 62, 1028-1034. [CrossRef]

26. Wang, B.J.; Dong, W.K.; Zhang, Y.; Akogun, S.F. A novel relay-sensor for highly sensitive and selective detection of $\mathrm{Zn}^{2+} / \mathrm{Pic}^{-}$and fluorescence on/off switch response of $\mathrm{H}^{+} / \mathrm{OH}^{-}$. Sens. Actuators B Chem. 2017, 247, 254-264. [CrossRef]

27. Wu, H.L.; Bai, Y.C.; Zhang, Y.H.; Pan, G.L.; Kong, J.; Shi, F.; Wang, X.L. Two lanthanide(III) complexes based on the schiff base $N, N$-Bis(salicylidene)-1,5-diamino-3-oxapentane: Synthesis, characterization, DNA-binding properties, and antioxidation. Zeitschrift für Anorganische und Allgemeine Chemie 2014, 640, $2062-2071$. [CrossRef]

28. Wu, H.L.; Pan, G.L.; Bai, Y.C.; Wang, H.; Kong, J.; Shi, F.; Zhang, Y.H.; Wang, X.L. Preparation, structure, DNA-binding properties, and antioxidant activities of a homodinuclear erbium(III) complex with a pentadentate Schiff base ligand. J. Chem. Res. 2014, 38, 211-217. [CrossRef]

29. Zheng, S.S.; Dong, W.K.; Zhang, Y.; Chen, L.; Ding, Y.J. Four Salamo-type 3d-4f hetero-bimetallic $\left[\mathrm{Zn}^{\mathrm{II}} \mathrm{Ln}^{\mathrm{III}}\right]$ complexes: Syntheses, crystal structures, and luminescent and magnetic properties. New J. Chem. 2017, 41, 4966-4973. [CrossRef]

30. Zhang, H.; Dong, W.K.; Zhang, Y.; Akogun, S.F. Naphthalenediol-based bis(Salamo)-type homo- and heterotrinuclear cobalt(II) complexes: Syntheses, structures and magnetic properties. Polyhedron 2017, 133, 279-293. [CrossRef]

31. Hao, J.; Li, L.L.; Zhang, J.T.; Akogun, S.F.; Wang, L.; Dong, W.K. Four homo- and hetero-bismetallic 3d/3d-2s complexes constructed from a naphthalenediol-based acyclic bis(salamo)-type tetraoxime ligand. Polyhedron 2017, 134, 1-10. [CrossRef]

32. Wang, L.; Li, X.Y.; Zhao, Q.; Li, L.H.; Dong, W.K. Fluorescence properties of heterotrinuclear Zn(II)-M(II) ( $\mathrm{M}=\mathrm{Ca}$, Sr and Ba) bis(salamo)-type complexes. RSC Adv. 2017, 7, 48730-48737. [CrossRef] 
33. Dong, W.K.; Ma, J.C.; Zhu, L.C.; Zhang, Y.; Li, X.L. Four new nickel(II) complexes based on an asymmetric Salamo-type ligand: Synthesis, structure, solvent effect and electrochemical property. Inorg. Chim. Acta 2016, 445, 140-148. [CrossRef]

34. Yang, Y.H.; Hao, J.; Dong, Y.J.; Wang, G.; Dong, W.K. Two znic(II) complexes constructed from a bis(salamo)-type tetraoxime ligand: Syntheses, crystal structures and luminescence properties. Chin. J. Inorg. Chem. 2017, 33, 1280-1292.

35. Dong, X.Y.; Gao, L.; Wang, F.; Zhang, Y.; Dong, W.K. Tri- and Mono-Nuclear Zinc(II) Complexes Based on Half- and Mono-Salamo Chelating Ligands. Crystals 2017, 7, 267. [CrossRef]

36. Li, G.; Hao, J.; Liu, L.Z.; Zhou, W.M.; Dong, W.K. Syntheses, crystal structures and thermal behaviors of two supramolecular salamo-type cobalt(II) and zinc(II) complexes. Crystals 2017, 7, 217.

37. Tao, C.H.; Ma, J.C.; Zhu, L.C.; Zhang, Y.; Dong, W.K. Heterobimetallic 3d-4f Zn(II)-Ln(III) (Ln = Sm, Eu, $\mathrm{Tb}$ and $\mathrm{Dy}$ ) complexes with a $\mathrm{N}_{2} \mathrm{O}_{4}$ bisoxime chelate ligand and a simple auxiliary ligand Py: Syntheses, structures and luminescence properties. Polyhedron 2017, 128, 38-45. [CrossRef]

38. Chen, L.; Dong, W.K.; Zhang, H.; Zhang, Y.; Sun, Y.X. Structural variation and luminescence properties of triand dinuclear $\mathrm{Cu}^{\mathrm{II}}$ and $\mathrm{Zn}^{\mathrm{II}}$ complexes constructed from a naphthalenediol-based bis(Salamo)-type ligand. Cryst. Growth Des. 2017, 17, 3636-3648. [CrossRef]

39. Song, X.Q.; Peng, Y.J.; Chen, G.Q.; Wang, X.R.; Liu, P.P.; Xu, W.Y. Substituted group-directed assembly of $\mathrm{Zn}(\mathrm{II})$ coordination complexes based on two new structural related pyrazolone based Salen ligands: Syntheses, structures and fluorescence properties. Inorg. Chim. Acta 2015, 427, 13-21. [CrossRef]

40. Dong, X.Y.; Kang, Q.P.; Jin, B.X.; Dong, W.K. A dinuclear nickel(II) complex derived from an asymmetric Salamo-type $\mathrm{N}_{2} \mathrm{O}_{2}$ chelate ligand: Synthesis, structure and optical properties. Zeitschrift für Naturforschung $B$ 2017, 72, 415-420. [CrossRef]

41. Dong, X.Y.; Li, X.Y.; Liu, L.Z.; Zhang, H.; Ding, Y.J.; Dong, W.K. Tri- and hexanuclear heterometallic $\mathrm{Ni}(\mathrm{II})-\mathrm{M}(\mathrm{II})(\mathrm{M}=\mathrm{Ca}, \mathrm{Sr}$ and Ba) bis(salamo)-type complexes: Synthesis, structure and fluorescence properties. RSC Adv. 2017, 7, 48394-48403. [CrossRef]

42. Zhao, L.; Wang, L.; Sun, Y.X.; Dong, W.K.; Tang, X.L.; Gao, X.H. A supramolecular copper(II) complex bearing salen-type bisoxime ligand: Synthesis, structural characterization, and thermal property. Synth. React. Inorg. Met.-Org. Nano-Met. Chem. 2012, 42, 1303-1308. [CrossRef]

43. Liu, Y.A.; Wang, C.Y.; Zhang, M.; Song, X.Q. Structures and magnetic properties of cyclic heterometallic tetranuclear clusters. Polyhedron 2017, 127, 278-286. [CrossRef]

44. Dong, W.K.; Wang, L.; Sun, Y.X.; Tong, J.F.; Wu, J.C. Synthesis and crystal structure of a bisoxime cobalt (II) complex. Chin. J. Inorg. Chem. 2011, 27, 372-376.

45. Song, X.Q.; Cheng, G.Q.; Liu, Y.A. Enhanced $\mathrm{Tb}(\mathrm{III})$ luminescence by $\mathrm{d}^{10}$ transition metal coordination. Inorg. Chim. Acta 2016, 450, 386-394. [CrossRef]

46. Gao, L.; Wang, F.; Zhao, Q.; Zhang, Y.; Dong, W.K. Mononuclear Zn(II) and trinuclear Ni(II) complexes derived from a coumarin-containing $\mathrm{N}_{2} \mathrm{O}_{2}$ ligand: Syntheses, crystal structures and fluorescence properties. Polyhedron 2018, 139, 7-16. [CrossRef]

47. Sheldrick, G.M. SHELXS-2014, Program for Crystal Structure Solution; University of Göttingen: Göttingen, Germany, 2014.

48. Sheldrick, G.M. SHELXL-2014, Program for Crystal Structure Refinement; University of Göttingen: Göttingen, Germany, 2014.

49. Chai, L.Q.; Wang, G.; Sun, Y.X.; Dong, W.K.; Zhao, L.; Gao, X.H. Synthesis, crystal structure, and fluorescence of an unexpected dialkoxo-bridged dinuclear copper(II) complex with bis(salen)-type tetraoxime. J. Coord. Chem. 2012, 65, 1621-1631. [CrossRef]

50. Dong, Y.J.; Ma, J.C.; Zhu, L.C.; Dong, W.K.; Zhang, Y. Four 3d-4f heteromultinuclear zinc(II)-lanthanide(III) complexes constructed from a distinct hexadentate $\mathrm{N}_{2} \mathrm{O}_{2}$-type ligand: Syntheses, structures and photophysical properties. J. Coord. Chem. 2017, 70, 103-115. [CrossRef]

51. Ma, J.C.; Dong, X.Y.; Dong, W.K.; Zhang, Y.; Zhu, L.C.; Zhang, J.T. An unexpected dinuclear Cu(II) complex with a bis(Salamo) chelating ligand: Synthesis, crystal structure, and photophysical properties. J. Coord. Chem. 2016, 69, 149-159. [CrossRef]

52. Dong, W.K.; Zhang, J.; Zhang, Y.; Li, N. Novel multinuclear transition metal(II) complexes based on an asymmetric salamo-type ligand: Syntheses, structure characterizations and fluorescent properties. Inorg. Chim. Acta 2016, 444, 95-102. [CrossRef] 
53. Wu, H.L.; Pan, G.L.; Wang, H.; Wang, X.L.; Bai, Y.C.; Zhang, Y.H. Study on synthesis, crystal structure, antioxidant and DNA-binding of mono-, di- and poly-nuclear lanthanides complexes with bis(N-salicylidene)-3-oxapentane-1,5-diamine. J. Photochem. Photobiol. B Biol. 2014, 135, 33-43. [CrossRef] [PubMed]

54. Xu, L.; Zhu, L.C.; Ma, J.C.; Zhang, Y.; Zhang, J.; Dong, W.K. Syntheses, structures and spectral properties of mononuclear $\mathrm{Cu} \mathrm{u}^{\mathrm{II}}$ and dimeric $\mathrm{Zn}^{\mathrm{II}}$ complexes based on an asymmetric Salamo-type $\mathrm{N}_{2} \mathrm{O}_{2}$ ligand. Zeitschrift für Anorganische und Allgemeine Chemie 2015, 641, 2520-2524. [CrossRef]

55. Chai, L.Q.; Huang, J.J.; Zhang, J.Y.; Li, Y.X. Two 1-D and 2-D cobalt(II) complexes: Synthesis, crystal structures, spectroscopic and electrochemical properties. J. Coord. Chem. 2015, 68, 1224-1237. [CrossRef]

56. Chai, L.Q.; Liu, G.; Zhang, Y.L.; Huang, J.J.; Tong, J.F. Synthesis, crystal structure, fluorescence, electrochemical property, and SOD-like activity of an unexpected nickel(II) complex with a quinazoline-type ligand. J. Coord. Chem. 2013, 66, 3926-3938. [CrossRef]

57. Dong, W.K.; Zheng, S.S.; Zhang, J.T.; Zhang, Y.; Sun, Y.X. Luminescent properties of heterotrinuclear 3d-4f complexes constructed from a naphthalenediol-based acyclic bis(salamo)-type ligand. Spectrochim. Acta A 2017, 184, 141-150. [CrossRef] [PubMed]

58. Sun, Y.X.; Lu, R.E.; Li, X.R.; Zhao, Y.Y.; Li, C.Y. A schiff base ligand containing oxime group and its Cu(II) complex: Syntheses and supramolecular structures. Chin. J. Inorg. Chem. 2015, 31, 1055-1062.

59. Chai, L.Q.; Li, Y.X.; Chen, L.C.; Zhang, J.Y.; Huang, J.J. Synthesis, X-ray structure, spectroscopic, electrochemical properties and DFT calculation of a bridged dinuclear copper(II) complex. Inorg. Chim. Acta 2016, 444, 193-201. [CrossRef]

60. Chai, L.Q.; Zhang, K.Y.; Tang, L.J.; Zhang, J.Y.; Zhang, H.S. Two mono- and dinuclear Ni(II) complexes constructed from quinazoline-type ligands: Synthesis, X-ray structures, spectroscopic, electrochemical, thermal, and antimicrobial studies. Polyhedron 2017, 130, 100-107. [CrossRef]

61. Chai, L.Q.; Tang, L.J.; Chen, L.C.; Huang, J.J. Structural, spectral, electrochemical and DFT studies of two mononuclear manganese(II) and zinc(II) complexes. Polyhedron 2017, 122, 228-240. [CrossRef]

62. Dong, W.K.; Lan, P.F.; Zhou, W.M.; Zhang, Y. Salamo-type trinuclear and tetranuclear cobalt(II) complexes based on a new asymmetry Salamo-type ligand: Syntheses, crystal structures, and fluorescence properties. J. Coord. Chem. 2016, 7, 1-22. [CrossRef]

63. Liu, P.P.; Wang, C.Y.; Zhang, M.; Song, X.Q. Pentanuclear sandwich-type Zn ${ }^{\mathrm{II}}$-Ln ${ }^{\mathrm{III}}$ clusters based on a new Salen-like salicylamide ligand: Structure, near-infrared emission and magnetic properties. Polyhedron 2017, 129, 133-140. [CrossRef]

64. Song, X.Q.; Cheng, G.Q.; Wang, X.R.; Xu, W.Y.; Liu, P.P. Structure-based description of a step-by-step synthesis of heterodinuclear $\mathrm{Zn}^{\mathrm{II}} \mathrm{Ln}^{\mathrm{III}}$ complexes and their luminescence properties. Inorg. Chim. Acta 2015, 425, 145-153. [CrossRef]

65. Sun, Y.X.; Zhao, Y.Y.; Li, C.Y.; Yu, B.; Guo, J.Q.; Li, J. Supramolecular cobalt(II) and copper(II) complexes with schiff base ligand: Syntheses, characterizations and crystal structures. Chin. J. Inorg. Chem. 2016, 32, $913-920$.

66. Chai, L.Q.; Mao, K.H.; Zhang, J.Y.; Zhang, K.Y.; Zhang, H.S. Synthesis, X-ray crystal structure, spectroscopic, electrochemical and antimicrobial studies of a new dinuclear cobalt(III) complex. Inorg. Chim. Acta 2017, 457, 34-40. [CrossRef]

67. Dong, Y.J.; Dong, X.Y.; Dong, W.K.; Zhang, Y.; Zhang, L.S. Three asymmetric Salamo-type copper(II) and cobalt(II) complexes: Syntheses, structures, fluorescent properties. Polyhedron 2017, 123, 305-315. [CrossRef]

(C) 2018 by the authors. Licensee MDPI, Basel, Switzerland. This article is an open access article distributed under the terms and conditions of the Creative Commons Attribution (CC BY) license (http://creativecommons.org/licenses/by/4.0/). 